\title{
Falling from horses: medical controversy in early eighteenth-century England
}

\author{
Stephen Pender \\ Department of English, University of Windsor, Ontario, Canada N9B 3P4 \\ ${ }^{\star}$ Corresponding author. Email: spender@uwindsor.ca
}

\begin{abstract}
On Tuesday, 12 April 1726, Robert Worger fell from his horse at Barnham Down, Kent, hitting his head on the ground 'with strong Force'. Unconscious, he was taken to Bridge, a nearby village, and laid out at the home of Sarah Knot, 'Nurse and Landlady to the Patient', bled several times, given 'volatile mixture' (ammonia, salt, opium) and treated with purgatives and clysters. He vomited as many as five times over the course of his illness and delivered 'half a score [of] very foul, stinking, loose Stools'. Worger died, 'without ... Agony', at 5 am, Thursday, 21 April 1726, after living for 8 days in the care of Knot, his wife, two surgeons, an assistant, an apothecary and two physicians, Christopher Packe and John Gray. An autopsy was performed - the next night, by the light of a single candle - and, although there was little extravasation and no severe fractures or depressions in the skull, slight abnormalities were found: the cerebellum 'Turgid with Blood', two small fissures appeared on the os frontis. Worger's illness and death spurred months of rebarbative public controversy: in order to exonerate themselves, both physicians published pamphlets and letters, secured affidavits, importuned surgeons and Worger's relatives for support, vied for authority and mastery over the circumstances of the case and argued about propriety, professionalism and conduct. This paper explores Worger's case controversy about diagnosis and prognosis, concern with 'knowledge and deportment', with the status of medical offices and medical jurisprudence and with relationships between physicians, patients, surgeons - as an instance of learned medical controversy in early eighteenth-century England.
\end{abstract}

Keywords: Medicine; Rhetoric; Medical controversy; Pulse; Apoplexy

On Tuesday, 12 April 1726, Robert Worger fell from his horse at Barnham Down, Kent, hitting his head on the ground 'with strong Force'. Unconscious, he was taken to Bridge, a nearby village, and laid out at the home of Sarah Knot, 'Nurse and Landlady to the Patient', bled several times, given 'volatile mixture' (ammonia, salt, opium) and treated with purgatives and clysters. He vomited as many as five times over the course of his illness and delivered 'half a Score [of] very foul, stinking, loose Stools'. ${ }^{1}$ Worger died, 'without ... Agony', at 5am, Thursday, 21 April 1726, after living for 8 days in the care of Knot, his wife, two surgeons, an assistant, an apothecary ${ }^{2}$ and two physicians, Christopher Packe and John Gray. An autopsy was performed - the next night, by the light of a single candle - and, although there was little extravasation, and no severe fractures or depressions in the skull, slight abnormalities were found: the cerebellum 'Turgid with Blood', two small fissures appeared on the os frontis.

\footnotetext{
${ }^{1}$ A Reply to Dr. Gray's Three Answers to a Written Paper, Entitled Mr. WORGER's Case (Canterbury, 1727), 4 (hereafter, 'P' and page number).

2'James Bexter, a Lad at Bridge, who shav'd Mr. Worger's Head' and 'Mr. Hatch the Patient's Apothecary' in John Gray, $A$ Further Answer, Being a True Representation of Mr. WORGER's Case, in Confutation of Dr. PACKE's Written Paper (Canterbury, 1726), 8-9 (hereafter, G2 with page numbers). Although his status is unnoticed in the pamphlets, clearly Worger's family could afford to contract several practitioners, and physicians were costly; see Ann Digby, Making a Medical Living: Doctors and Patients in the English Market for Medicine, 1720-1911 (New York: Cambridge University Press, 1994).
}

(C) The Author(s), 2020. Published by Cambridge University Press. 
Worger's fall, illness and death spurred private and public controversy well into the autumn of 1727. In a series of manuscripts, letters and pamphlets conceived to defend their clinical conduct, Worger's physicians debated aetiologies, diagnoses and treatments, propriety and professionalism. The more wellknown physician, Packe, is certainly practised at controversy, as he attempted to forestall the affair by privately disseminating papers detailing the case, his role and his care, shortly after the patient's death. Gray objected in the form of two pamphlets, 'answers' to Packe's manuscript historia, which he obtained 'by Accident' (G2, 1-5). Gray's first pamphlet is brief, pointed, but his second, longer piece offers a full account of the case in order to 'satisfy any unpred'c'd Reader of the Truth and Justice of [his] Cause' (G2, 1). As he secures a number of affidavits supporting his own view of the accident and its effects, Gray urges Packe to make public his observationes. ${ }^{3}$ To these interventions, Packe responded in 1727 in a pamphlet and in three letters sent to The Kentish Post: or Canterbury News-Letter, in October $1726 .{ }^{4}$ Attempting to triumph with gross volubility, his response to Gray's two mildly vituperative pamphlets, some 17 pages in all, runs to 71 footnoted pages, replete with classical and contemporary medical and philosophical citations, from Galen through Forestus to Pitcairn, in English and Latin. Where Gray is modest and clear, Packe is pyrotechnic, rebarbative, florid - paradoxically so, for his remonstrance conjures decorum and character, 'Breeding' and 'integrity', over and again. Gray's actions and opinions rile the 'Honourable Art of Physick' itself $(\mathrm{P}, 58)$. For his part, Gray refuses 'hot Words', but Packe is heated and thought Gray's arguments burlesque (G2, 1, 5; P, 51). As this exchange, its barbs and feints, unfolds, the 'Formality that is usual between Physicians and Surgeons' (P, 45) is dissolved in envy, malice and pique.

Harold J. Cook has claimed that learned physicians frowned on advertising their practice, demurred when it came to discussing fees and 'generally tried to avoid becoming personally involved in public medical disputes' - a surprising claim, for physicians had debated status and method, theory and practice, with apothecaries, surgeons and one another with frequency and intensity in the latter half of the seventeenth through to the end of eighteenth century. Some of these controversies reached as far as the House of Lords..$^{5}$ In 1951, Bernice Hamilton argued that two developments distinguish the medical profession in the eighteenth century: changes in medical training, imported to England from Edinburgh and Leiden, and 'professional feeling', arising from the 'struggle' for reform and improved status. ${ }^{6}$ That struggle takes place in institutions, of course, but also in the public sphere, as well in London as in Canterbury and Bridge, Kent: Worger's case allows us to see not only the syntax and vehicles of local medical controversy, as both physicians exercise formidable rhetorical powers, in the pamphlets and letters they published and, one assumes, in missives exchanged, but durable concerns for reputation that supersede their immediate care for Worger. Here, in three sections, outlined below, I detail not only the dispute and the condition of the patient, but also the physicians' divergent diagnoses, focussing on the pulse and phlebotomy, trepanation and apoplexy, in order to demonstrate that - despite the fact that I can find no court or assize records at Kent or at Kew that clear either physician from blame - this controversy evidences an array of early modern medical concerns, including questions of conduct, politesse and status, for these two physicians confirm as much as they gainsay the boundaries of 'polite

\footnotetext{
${ }^{3}$ A Short Answer to a Written Paper Privately Handed About by Dr. Packe, Entitled Mr. Worger's Case (Canterbury, 1726), 8 (hereafter, G1 with page numbers).

${ }^{4}$ All of these publications, including the Canterbury News-Letter and, later, Packe's Ankographia, were printed at a prominent Canterbury house; see David Shaw and Sarah Gray, 'James Abree (1691?-1768): Canterbury's First "Modern" Printer', in P. Isaac and B. McKay (eds), Making, Selling, and Reading Books (Winchester: St. Paul's Bibliographies, 1998), 21-6.

${ }^{5}$ Harold J. Cook, in W.T. Reich (ed.), Medical Ethics, History of Europe IV: 'Renaissance and Enlightenment', in Encyclopedia of Bioethics, revised edition (New York: Simon and Schuster Macmillan, 1995), 1541-2. See Bernice Hamilton, 'The Medical Profession in the Eighteenth Century,' The Economic History Review 4 (1951), 163-4; Harold J. Cook, 'The Rose Case Reconsidered: Physicians, Apothecaries, and the Law in Augustan England', Journal of the History of Medicine and Allied Sciences 45 (1990), 527-55. See also Tobi Gelfand, Professionalizing Modern Medicine: Paris Surgeons and Medical Science and Institutions in the Eighteenth Century (Westport: Greenwood Press, 1980); Dorothy and Roy Porter, Patient's Progress: Doctors and Doctoring in Eighteenth-Century England (Stanford: Stanford University Press, 1989); Alan G. Debus, Chemistry and Medical Debate: van Helmont to Boerhaave (Canont: Science History Publications, 2001), esp. $175 \mathrm{ff}$.

${ }^{6}$ Hamilton, op. cit. (note 6), 141.
} 
science', conversations appropriate and becoming, in Packe's terms, to gentlemen, physicians and scholars $(\mathrm{P}, 25)^{7}$

While Packe advances chemical remedies for Worger's condition, and Gray is rather more conventional in theory and practice, both physicians occupy a world of shared Galenic medical thought, its eclecticism displayed in print and in person as a confected mix of ancient texts and Christian learning, late scholasticism and the new philosophy. ${ }^{8}$ This is true of eighteenth-century medicine in general: as Ann Thompson has shown, divergent forms of materialism, vitalism and animism often drew on similar sources and ideas. ${ }^{9}$ As we shall see below, despite varying theoretical commitments - to mechanism, to chemistry - physicians generally agree on the aetiology and treatment of apoplexy, for example. Flexible, adaptable Galenic habits of thought both underwrite Packe and Gray's vexed conversations and allow for substantial disagreement about matters physiological, diagnostic and therapeutic. If this is a tale of the ways in which broad, eclectic medical learning shapes debate, it is also a local story, set in a milieu populated by surgeons and neighbours, supporters and detractors and by those who published and read the physicians' defences. ${ }^{10}$ We catch a brief glimpse of women's medical experiences, too, in Worger's nurse and his wife.

Who were these disputatious practitioners? About Gray we know little: apparently he was a companion of the physician and natural philosopher William Stukeley, when Stukeley was at Cambridge pursuing his bachelor of medicine (1703-8). As one early biographer suggests, Stukeley 'took frequent perambulations through the neighbouring country, with the famous Dr. Hales, Dr. John Gray of Canterbury and others, in search of plants'. ${ }^{11}$ Like many physicians in the period, Gray had interest in botany. Packe is rather more well known, but one must disentangle Packes père et fils. The first Christopher Packe was a successful London physician who balanced empiricism with erudition in his 'Chymical Practiss'. ${ }^{12}$ His Medela chymica (1708) is a rich store of case histories, consilia and obversationes, that he calls a 'little History of Cures'. If we take him at his word, Packe père is compassionate, for 'in very painful diseases', he found it difficult 'to keep a patient from opiates'. ${ }^{13}$ He published fairly widely, including a translation of a Latin treatise on the pancreas and an edition of chemical aphorisms, signed 'Philo-Chymico-Medicus'. ${ }^{14}$ Packe's grandson, the third Christopher Packe (d. 1800), was a member of the Medical Society of Edinburgh, admitted by 3 March 1750 and published 'A Commentary on Boerhaave's Aphorisms on the Phthisis Pulmonalis', in The Medical Register for the Year 1780, which

\footnotetext{
${ }^{7}$ On politeness in natural philosophy and medicine, see Steven Shapin and Simon Schaffer, Leviathan and the Air-Pump: Hobbes, Boyle, and the Experimental Life (Princeton: Princeton University Press, 1985); Larry Stewart, The Rise of Public Science: Rhetoric, Technology, and Natural Philosophy in Newtonian Britain, 1660-1750 (Cambridge: Cambridge University Press, 1992); Lawrence Klein, Shaftesbury and the Culture of Politeness: Moral Discourse and Cultural Politics in Early Eighteenth-Century England (Cambridge: Cambridge University Press, 1994); Alice N. Walters, 'Conversation Pieces: Science and Politeness in Eighteenth-Century England', History of Science 35 (1997), 121-54; Paul Langford, 'The Uses of EighteenthCentury Politeness', Transactions of the Royal Historical Society 12 (2002), 311-31.

${ }^{8}$ See Harold J. Cook, 'Physicians and the new philosophy: Henry Stubbe and the Virtuosi-physicians', in R. French and A. Wear (eds), Medical Revolution in the Seventeenth Century (Cambridge: Cambridge University Press, 1989), 246-71; H. Steinke and M. Stuber, 'Medical Correspondence in Early Modern Europe: An Introduction', Gesnerus 61 (2004), 139-60.

${ }^{9}$ Ann Thomson, Bodies of Thought: Science, Religion, and the Soul in the Early Enlightenment (Oxford: Oxford University Press, 2008), 13, 16-17, 67, 81-3, passim.

${ }^{10}$ On the persistence of Galenism and this 'shared medical world', see Owsei Temkin, Galenism: Rise and Decline of a Medical Philosophy (Ithaca: Cornell University Press, 1973), esp. 135, 165ff and Michael Stolberg, Experiencing Illness and the Sick Body in Early Modern Europe, trans. L. Unglaub and L. Kennedy (Basingstoke: Palgrave Macmillan, 2011). While medical theory changes rapidly - humours and spirits superseded by nerves, fluids and solids - medical practice remains largely organised by more or less constant Galenic categories, and forms of intervention, well into the eighteenth century.

${ }^{11}$ John Nichols et al., Literary Anecdotes of the Eighteenth Century ... (London: Nichols and Son, 1812), vol. 5, 499.

${ }^{12}$ Medela chymica: or, an Account of the Vertues and Uses of ... Chymical Medicines (London, 1708), 32, 37, sig. A3r.

${ }^{13}$ Ibid., 146, 13, 42ff., 50ff., 52.

${ }^{14}$ Regnerus de Graaf, Succo pancreaticao: or, a Physical and Anatomical Treatise of the Nature and Office of the Pancreatic Juice (London, 1676); One Hundred and Fifty Three Chymical Aphorisms (London, 1688).
} 
was printed on its own in $1754 .{ }^{15}$ The Packe that is our concern lived from 1686 to 1749 , likely the son of the chemist, and practised medicine in a mathematical Way, and upon what he calls the Doctrine of Hydraulicks' (G2, 10). Citing Bellini's De missione sanguinis (1698) and J. Keill's Tautanima medicophysica (1718), Packe confirms that he views the circulation of the blood and the pulse hydraulically, a 'manner of reasoning ... supported by Authors of the best Credit' (P, 52). He was a candidate for fellowship in the College of Physicians ${ }^{16}$ and one of the many correspondents of Sir Hans Sloane. He warrants a brief biography in the Oxford Dictionary of National Biography, but there are few scholarly examinations of Packe. Saul Jarcho's 1978 appreciation, in which he details his life and work, argues that his medical thought informs his other work: 'Packe concatenated physiological knowledge, topographic observation, cosmologic hypothesis, and Biblical legend'. Jarcho does not examine his 'minor writings', precisely the subject of this paper. ${ }^{17}$ Most other scholarly attention has been directed to his choreography. ${ }^{18}$ As Packe confesses, 'I write ... [as] a Naturalist who desires to be readily understood by all sorts of Readers', noting the 'Care and Thought' required for his large-scale map of 16 miles of Kent, its minute features delineated using a compass set to magnetic north. He observes, describes and measures the county, presenting the world with a model 'for the Study of Nature', his data gathered on his medical rounds. ${ }^{19}$ Packe's observations include confirming Barnham Down, where Worger fell from his horse, as the main encampment for Caesar's armies in England. ${ }^{20}$

With a focus on the accident at Barnham Down and its afterlife, this paper unfolds in three sections, the first of which treats the fall itself. Second, I explore contemporary medical thought about Worger's sickness and care and, here, uncertainty reigns, played out in differences of opinion concerning diagnosis, prescription, the pulse, bleeding, present in the arguments between Packe and the two surgeons conscripted by Gray for their opinions on Worger. In the last section, I treat the physicians' vituperative rhetoric, their charges against one another's character, comportment and practice, their interactions with surgeons and Worger's family and their attempts to shift and transfer blame for his death. This is a full-dress, sometimes noisome, public debate, in pamphlets, letters, affidavits, that seems to have garnered enough attention to enlist the local Canterbury newsletter. The physicians' lengthy, pugnacious quarrel speaks to the significance of professional decorum and reputation, to conflicts between learned medical practice and surgical techniques, to the ways in which medical thought is both capacious and responsive to individual practitioners.

\section{Falling}

That evening at Barnham Down, Worger was in company, but we do not know the purpose of his ride, save that 'Riding with a good Horse and a good Companion' is salutary recreation. ${ }^{21}$ Riding is mentioned frequently in the period under the non-natural category 'exercise and rest' (the others are food and drink,

\footnotetext{
${ }^{15}$ Index librorum Societatis Medicee Edinensis (Edinburgh, 1766), 37; The Medical Register for the Year 1780 (London, 1780), 104.

${ }^{16}$ As Harold Cook explains, a 'candidate' is essentially a fellow-in-waiting, elected during a period when the statutory number of fellows was complete (The Decline of the Old Medical Regime in Stuart London [Ithaca: Cornell University Press, 1986], 75).

${ }^{17}$ Saul Jarcho, 'Christopher Packe (1686-1749): Physician-Chorographer of Kent', Journal of the History of Medicine and Allied Sciences 33 (1978), 47-52; 50, 48.

${ }^{18}$ See, eg., Michael Charlesworth, 'Mappying, the Body, and Desire: Christopher Packe's Chorography of Kent', in Denis Cosgrove (ed.), Mappings (London: Reaktion, 1999), 109-24; Matthew H. Edney, 'Reconsidering enlightenment geography and map making: reconnaissance, mapping, archive,' in D.N. Livingstone and C.W.J. Withers (eds), Geography and Enlightenment (Chicago: University of Chicago Press, 1999), 165-98 and, idem, 'Cartography without "Progress": Reinterpreting the Nature and Historical Development of Mapmaking,' Cartographica 30 (1995), 54-68.

${ }^{19}$ Christopher Packe, Ankographia: sive, Convallium descriptio, in which are Briefly but Fully Expounded the Origine, Course and Insertion; Extent, Elevation and Congruity of all the Valleys and Hills, Brooks and Rivers, ... of East-Kent (Canterbury, 1743), $15,97-8,101,103-6,52-6$.

${ }^{20}$ Ibid., 172-6.

${ }^{21}$ Henry Peacham, The Worth of a Penny (London, 1677), 30; see idem, The Compleat Gentleman (London, 1627), 186-7.
} 
excretion, sleep, air or environment, the passions, sometimes baths, massage, coitus), a way of enlivening the vital and animal spirits. Generally healthy, riding is sometimes recommended for specific ailments: for example, abdominal ulcers are shaken and loosed. ${ }^{22}$ Still, care should obtain, as riding can cause impotence by 'pressure and friction' on the vas deferens ${ }^{23}$ and falls from horses were common ${ }^{24}$ William III's being the most famous, although it was not, as is commonly assumed, the cause of his death. Rather, having fallen from horse on 21 February 1702, his autopsy revealed that William likely died of pneumonia a fortnight later, his lungs full of a 'purulent or frothy serum' ${ }^{25}$ Recovery from such accidents was uncertain but, as one physician claims late in the century, 'I have known a gentleman after falling from his horse, lie for many weeks oppressed, and in a coma ... who yet recovered perfectly'. Even in cases which receive immediate care, where a patient is surrounded by friends and surgeons, 'still we are not without our fears'. ${ }^{26}$ Of course, there were many such mishaps in the period. ${ }^{27}$

Suppositions about the accident inaugurate disagreement. Packe's description is brief but advances the notion that Worger fell twice: someone in his company collided with the rider, but Worger 'so well recover'd Himself, that he rode on about Two Poles, when, without further Violence, he fell from his Horse, as in an Apoplexy, without once Stirring any part of his Body' (P, 1). Packe is certain that Worger, before his ride, already suffered from 'swimming and giddiness in the Head', indicative of lethargy or apoplexy, about which Worger complained in advance of his ride. For this condition, the patient was bled the morning of the accident (P1, passim; see G1, 6, 8; G2, 1). In contrast, Gray asserts that, during the collision, Worger was thrown from his horse 'with the greatest Violence imaginable', citing several 'Eye-witnesses of this fatal Accident' (G2, 5, 2-3). Further, Worger's widow declares that her husband was not bled that morning, and 'went out from Home in perfect Health' (G1, 6; G2, 2; see below). Gray insists on the deleterious effects of the one and only fall, as he found Worger concussed, confused, incontinent, void of all sense and feeling, even when pinched. These and other symptoms 'ground [his] Prognosticks' $(\mathrm{G} 2,11)$.

About these details, Gray has testimonial proof: in order to correct Packe's misprision, he published a collection of affidavits, from local residents familiar with Worger, the ride and his fall, in late 1726. Several deponents, including those on the down that evening, endorse Gray's views. John Moate's is exemplary and worth quoting at length:

Mr. WORGER of Hinxhill fell off his Horse in the following manner; As he was riding with Violence, and another riding full speed directly towards him, they both met in their full Career; upon which Mr. WORGER was immediately carted off, and fell with the greatest Violence upon the hind part of his Head, in such a manner, that he doth believe if a Person was to strike the Ground with all the strength he could with a Beetle [an heavy, wooden instrument, used for driving, crushing, flattening], he could not make a greater Sound than his Head upon the Ground by the Violence of the Fall; And the father deposeth, that he was the Man who took Mr. WORGER from the Ground, and thought him dead; and that he believes he was within the Distance of two or three Rods at farthest [about 10 to 14 metres], to the best of his Remembrance, when this sad Accident happen'd.

\footnotetext{
${ }^{22}$ Giorgio Baglivi, The Practice of Physick, no. trans., 2nd edn (London, 1723), 143.

${ }^{23}$ Foucher d'Obsonville, Philosophic Essays on the Manners of Various Foreign Animals, Thomas Holcroft (trans.) (London, 1784), 265.

${ }^{24}$ As Thomas Willis writes, 'I know an eminent nobleman who having fallen off his horse ... suffered from paralysis of one leg for many years, and from weakness of the nerves' (Kenneth Dewhurst, Thomas Willis's Oxford Lectures [Oxford: Sanford, 1980], 76).

${ }^{25}$ [White Kennett], A Complete History of England ... to the Death of His Late Majesty King William III, 2nd edn, 3 vols (London, 1719), 3.835-37. The other famous fall is Montaigne's, detailed in 'Of Practice,' Donald Frame (trans.) The Complete Essays of Montaigne (Stanford: Stanford University Press, 1958), 268-70.

${ }^{26}$ John Bell, Discourses on the Nature and Cure of Wounds (London, 1795), 153, 35.

${ }^{27}$ Peter Edwards, Horse and Man in Early Modern England (London: Hambledon Continuum, 2007), 69-70, passim; see also Joan Thirsk, Horses in Early Modern England: For Service, for Pleasure, for Power (Reading, 1977); P. Edwards et al. (eds), The Horse as Cultural Icon: The Real and the Symbolic Horse in the Early Modern World (Leiden: Brill, 2011); Kevin de Ornellas, The Horse in Early Modern English Culture: Bridled, Curbed, and Tamed (Madison: Farleigh Dickinson University Press, 2014).
} 
A violence collision at the down, a fall on the 'hind' part of his head, a loud thump and an eye-witness presumed Worger dead: another deponent notes that Worger was 'flung with all the Violence imaginable off his Horse immediately'. At least two other witnesses confirm as much $(\mathrm{G} 2,2) .{ }^{28}$ Gray's account has weight.

Packe disagrees sharply: he asserts that Worger suffered from giddiness, occasionally compromising his sight, while Gray, and his deponents, testifies to a violent fall alone as the cause of his condition. He rode in 'perfect Health'. ${ }^{29}$ This inspires a searing attack on Mrs. Worger's reliability, as it transpires that she is Gray's cousin; neither can she properly judge a medical condition for her 'Want of Skill'. Still, one of Packe's supporters testifies that he was, in fact, not well the morning of the ride (P, 10, 38-39, 34, 60), and he attempts to buttress his assessment by insisting that Gray's account is 'highly Improbable'. Indeed, Packe finds it incredible, at least to anyone of 'Common Judgment', that so violent a fall would produce no deep wounds in the skull, no external 'Sign of Hurt', no muscle strain in the neck or shoulders. He is again hot when he asks: 'Can any one imagine, that I would designedly Forge a Story or two about a Man's Fall and his Constitution ...?' (P, 37-38, 58). His question, of course, Gray answers, and the contest begins. This disjunction - two falls or one? previous condition or not? - remains unresolved, but it underwrites both physicians' diagnosis and treatment, and these divergences, as well as mutual opprobrium and professional rivalry, cement their moral, and moralising, attitudes towards one another. Pre-existing 'giddiness' moves Packe to prescribe opium, for example, while the severity of the fall, and the suspicion of extravasation, suggests trepanation to Gray. Where does this leave the patient? By the end of the day on which he fell from his at Barnham Down, 40-year-old Worger was 'cold, without Sense or Motion' (P, 1).

\section{Trepanning, apoplexy, bleeding}

Differing about the cause, or causes, of Worger's stupor occasions several skirmishes. Packe and Gray quarrel about the patient's symptoms, particularly his pulse; they disagree about the quantity of blood to let, and they break decisively about his need for surgery. This section explores their clinical acumen and their practice in the context of seventeenth- and eighteenth-century medical thought. Packe claims Worger had a pre-existing condition, 'swimming in the head', that indicates apoplexy (P, 1, 34, 54): Was he already apoplectic, a condition exacerbated by his fall, or did he suffer sharply from the accident alone? Was his pulse strong or weak? Were the surgeons, Crayford and Botting, too eager to deploy their awls and burins?

Surgery first: a day after Worger's decubitus, his 'lying down', Gray proposes trepanning for what he assumes is extravasated blood in the skull, about which Packe is furious, appearing at Bridge either to prevent or at the very least witness the operation (see G1,7). After meeting with both physicians on the same day, Wednesday, at least one surgeon, Crayford, counselled trepanning if 'Symptoms did not remit' $(G 2,3)$. Endorsing this course of action, Gray asserts that, as most practitioners attest, trepanation is essential in relieving concussion: 'all this Noise against Trepanning is only because, the Doctor says [Packe], that the Patient had not so much as a broken Head', although 'a Fissure was actually found after Death' $(\mathrm{G} 2,12)$. Trepanation was used to remove fragments of bone from the head, to restore a 'depressed' part of the skull or to discharge 'matter or coagulated blood collected between the skull and the membrane dura mater' resultant from fissures, fractures or contusions. The procedure is to be used rarely and carefully. ${ }^{30}$ That the dura mater is damaged is known by impairment of the senses, and that the brain is injured by is disclosed in loss of speech, syncope, vomiting, fever, delirium and apoplexy. Quite often, these injuries and impairments arise from 'extravas'd Blood, which ferments, pricks, and brings on an Inflammation', and frequently cause feinting and falling, as 'compression' in the brain

\footnotetext{
${ }^{28}$ Copies of Affidavits Made at the Request of Dr. Packe, and Publish'd for his Use (Canterbury, 1726), 8, 1-3.

${ }^{29}$ Ibid., 3.

${ }^{30}$ As recommended by the surgeon royal, John Browne, A Compleat Discourse of Wounds (London, 1678), 140-1. In general, see Charles G. Gross, A Hole in the Head: More Tales in the History of Neuroscience (Cambridge: MIT Press, 2009), 3-24.
} 
interrupts the course of animal spirits. ${ }^{31}$ These signs are certainly similar to Worger's, and thus Gray is warranted in considering opening the patient's skull.

The middle of Worger's illness was busy with consultation, just as the village was alive with gossip: Packe reproduces no fewer than 10 letters, exchanged on Wednesday and Thursday, 13 and 14 April, about the possibility of trepanning. At 1 o'clock on Thursday, from Bridge, Packe writes to Gray: 'I aver to you, that there is not only no occasion for the OPERATION, but ALL REASON AGAINST IT' (P, 11). To substantiate his opinion, Packe gathers several supportive depositions (P, 30-33), the most important of which is from a surgeon, Spratt, given 15 November, 1726, more than 6 months after Worger died. This detailed testimony begins with the surgeon inquiring of Packe whether or not Worger is to be trepanned, which is 'Common Discourse' at Bridge's public house, the Lion. Packe read to Spratt and others some of Gray's letters, and then Spratt and Packe visited Worger, where they found faring poorly. Spratt examined Worger's skull and 'found neither Wound nor Contusion, nor so much as the Least Scratch upon the Scalp', obviating the need to trephine ( $\mathrm{P}, 33-34)$. Finally, Packe himself asserts that, since there are no external indications of extravasation, using an awl would expose the patient to 'unnecessary Hazard' (P, 40, 44, 46). In the end, despite the wrangling, it seems that neither surgeon performed the operation, as we learn from the pamphlets and the brief autopsy, in which Worger's skull was reported to show no signs of fracture, no 'depression', though there were slight fissures in the orbital and squamous bones $(\mathrm{P}, 7)$.

Explaining away the small fissure on the forehead is Packe's tour-de-force: only an avaricious and vainglorious surgeon would recommend trepanning in such cases, for Packe is sure that the cracks and fissures that appear on the skull were caused post-mortem, by Worger's head striking the 'Coffin-Lid, thro' the Ruggedness of the Ways', after he was carried 'fourteen (no very smooth) miles' from Bridge to the autopsy. Small fissures like these are common, he insists, and are confirmed by examining 'the Heads of Persons carry'd such a distance to their Interment' ( $\mathrm{P}, 46,48-49)$. Perhaps the learned doctor doth protest too much.

Packe objects, too, to Gray's reading of Worger's pulse: dissensus emerges early in the debate and much of the patient's therapy depends on pulse-taking. Sphygmology was an ancient practice, developed and refined by Galen, for whom pulse-taking was a significant diagnostic aid. Pulse-taking could either confirm diagnosis reached by other means - palpation, for example - or offer its own. ${ }^{32}$ In Nicholas Culpeper's mid-seventeenth-century translation of Galen's Art of Physick, the pulse appears as an indication of the temperature and qualities of the heart and as a sign of temperament. ${ }^{33}$ In Western medicine, urine and the pulse are critical signs, as well as 'emblems of the rational physician's ability to see the invisible inner workings of the body'. The pulse is an 'index' of innate heat, of the functioning of vital spirits. In particular, the pulse allows physicians to distinguish kinds of fevers, their origins, species and genera. ${ }^{34}$ Galen famously identified 27 kinds of pulse, with attention to magnitude, frequency, speed and regularity. ${ }^{35} \mathrm{He}$ wrote extensively about 'simple, compound, long, large, elevated, quick, frequent, vehement or strong, slow, weak, soft, equal, unequal, intermittent, dicrotus or double stroke, undulating,

\footnotetext{
${ }^{31}$ Edward Dunn, A Compendious and New Method of Performing Chirurgical Operations (London: Charles Rivington, 1724), 103-5. See also Charles Le Clerc, The Compleat Surgeon: Or, the Whole Art of Surgery Explain'd, no trans., 6th edn (London, 1727), 180-90 for uses and procedures; Robert Mynors, A History of the Practice of Trepanning the Skull (Birmingham: Piercy and Jones, 1785), a comprehensive tract tracing the operation from Hippocrates to Mynors' contemporaries. His introduction details a debate similar in tone and substance to the one under scrutiny here, between Mynors and the famous physician, later president of the Medical Society of London, Samuel Foart Simmons (iii-xii), as well as a detailed case history of a man whose head was fractured by a brick (120-30).

${ }^{32}$ Vivian Nutton, 'Galen at the Bedside: the Methods of a Medical Detective,' in W.F. Bynum and Roy Porter (eds), Medicine and the Five Senses (Cambridge: Cambridge University Press, 1993), 7-16; 12-3; Jerome J. Bylebyl, 'Galen on the Non-Natural Causes of Variation in the Pulse,' Bulletin of the History of Medicine 45 (1971), 482-85.

${ }^{33}$ Galen's Art of Physick, N. Culpeper (trans.) (London, 1662), 60-3, 81-99.

${ }^{34}$ Faith Wallis, 'Signs and Senses: Diagnosis and Prognosis in Early Medieval Pulse and Urine Texts,' Social History of Medicine 13 (2000), 268, 270.

${ }^{35}$ See C. R. S. Harris, The Heart and Vascular System in Ancient Greek Medicine from Alcmaeon to Galen (Oxford: Clarendon Press, 1973).
} 
trembling, convulsive pulses \& $c^{\prime} \cdot{ }^{36}$ A renewed interest in the pulse emerges in the seventeenth and early eighteenth centuries, in part because of 'mathematical medicine' and in part because of new means of measuring the pulse. ${ }^{37}$

Nevertheless, as an indication of a sufferer's condition, the pulse is, in the words of one eighteenthcentury physician, 'deceitful'. ${ }^{38}$ Worger's pulse is uneven: for his disposition, 'a laborious Countryman', to Packe his pulse is small, intermittent, diminishing as his illness unfolds, weakest on Monday, 18 April, 2 days before his death $(\mathrm{P}, 1-4)$. In contrast, Gray finds his pulse 'very strong and full' and, mid-week, proposes further bleeding:

To this the Doctor [Packe], in an angry manner, as is well known to the Company then present, reply'd, It was a small and broken Pulse, and said he should not be blooded. Upon which I referr'd the Feeling of the Pulse to the two Surgeons present. They both, upon Feeling, asserted it was very full and strong. I told the Doctor then, I hop'd he was satisfied; desiring he would not contradict me for Contradiction sake. The Doctor still most vehemently urging that the Pulse was small and broken, I express'd myself with some Warmth, and signify'd, that I would instantly leave the Patient to him, because we two could not agree. ... Upon [the surgeon] Mr. Crayford's interposing, during our Debate about the Pulse, and declaring his Opinion as to the Necessity of a farther and immediate Bleeding, and that plentifully too, from the Fulness of the Pulse, and upon his being so free in telling the Doctor that I was right, it must be remember'd that the Doctor put himself into a violent Passion, and told Mr. Crayford ... That he was only a Surgeon, and he would not hear him, whatever he had to say should be in Writing. I endeavour'd to pacify the Doctor, telling him, It was a Surgeon's Business as well as ours, and that he ought to hear a Surgeon speak; this is all, I can possibly conceive, that made the Doctor take upon him to assert in his written Paper, that I join'd with Mr. Crayford at that time about the Reasonableness of the Operation of the Trepan. $(G 2,5)$

Clearly, Worger's pulse varied in strength, magnitude and frequency over the course of his illness, but both physicians relied on their divergent readings as indications for treatment. Packe seems incorrigible, and if we credit the other physician, Packe's sense of hierarchy, of physicians' superiority to surgeons, leitmotifs in the exchange, is on display here. Gray calmly asserts his expertise in sphygmology in order to sue for his diagnosis, concussion, which is partly surgeons' business.

As a contemporary surgeon avers, falls 'bruiseth and conquassateth ['shakes together'] the Brain' in ways that blood 'remaineth extravasate', causing 'Vomiting, Delerium, loss of Speech, and what not'. As remedy, the patient is laid out, his feet stimulated with 'a forcible stroke' using a piece of wood, bled, then glistered. Only if necessary is the patient trepanned. ${ }^{39}$ The constituents of this distemper, and its treatment, remain more or less stable over the course of the eighteenth century. An eighteenth-century medical dissertation advances the same description of concussion - especially the absence of sense and voluntary motion, the depression of respiration and pulse - and the patient's 'breathing is deep,

\footnotetext{
${ }^{36}$ William Black, An Historical Sketch of Medicine and Surgery, from Their Origin to the Present Time (London, 1782), 94-5; Peter Pecic, 'Music, Mechanism, and the "Sonic Turn" in Physical Diagnosis,' Journal of the History of Medicine and Allied Sciences 71 (2015), 144-72; Nancy Siraisi, 'The Music of the Pulse in the Writing of Italian Academic Physicians (Fourteenth and Fifteenth Centuries),' Speculum 50 (1975), 689-710.

${ }^{37}$ See, eg., John Floyer, The Physician's Pulse-Watch (London: Smith and Benj. Watford, 1707); James Nihell, New and Extraordinary Observations Concerning the Prediction of Various Crises by the Pulse (London: Society of Booksellers for Promoting Learning, 1741), based on the work of Francisco Solano de Luque, that claims certain relationships between variations in the pulse and medical crises, particularly in fever. Nihell is skeptical. On Santorio's early seventeenth-century work on the pulse, see Fabrizio Bigotti and David Taylor, 'The Pulsilogium of Santorio: New Light on Technology and Measurement in Early Modern Medicine,' Societate si Politica 11 (2017), 55-114.

${ }^{38}$ 'The Pulse is deceitful, and the Patient himself is oft ignorant: These then, I say, are not sufficient grounds for him to proceed upon ...' (David Irish, Levamen infirmi: Or, Cordial Counsel to the Sick and Diseased [London: Author, 1700], 9).

${ }^{39}$ John Moyle, The Experienced Chirurgion (London: W. Davis and R. Gibson, 1703), 212-13; for a similar description, and cure, see Dale Ingram, Practical Cases and Observations in Surgery (London: J. Clarke, 1751), 77-100.
} 
sonorous, labourious and slow; the pulse irregular, labouring and oppressed'. The intellectual faculties, sense and motion are impaired, while vital functions often continue. Only if the patient improves, does the pulse become full, regular, quick. ${ }^{40}$ Aetiologies of concussion seem to confirm Gray's opinion: at first irregular and weak, the pulse grows gradually stronger, more frequent, as symptoms abate. What of Packe's opinion, then, that Worger suffered from 'giddiness'? Given what he claims is existing lightheadedness, Packe diagnoses Worger 'LETHARGIC or APOPLECTIC' or, hedging slightly, 'Apoplectic by Concussion' (P, 16, 23, and see 53-4, 61): his fall might have hastened his death, but apoplexia - or percutio, 'to strike', from which we derive the term 'stroke' 41 - is its cause. In certain ways, contemporary descriptions of the distemper seem to mirror Worger's symptoms, perhaps as much as they fit Gray's diagnosis of concussion.

Gray is unremitting: 'all the Mischief the poor Patient suffer'd, was from the prodigious and most violent Shock or Concussion receiv'd o the Brain by his Fall, which was the Occasion of his Death, and not the Fall occasion'd by an Apoplexy, as the Doctor himself insinuated' (G2, 6). Yet concussion, lethargy, some sleep disorders and apoplexy present similarly; given Worger's state, disentangling one condition from another, prescribing this or that regimen of cure, is vexing. ${ }^{42}$ It may be, as one practitioner sneers, that physicians invent 'new indications' to 'denote' a new set of diseases, matching signs to their hypotheses. ${ }^{43}$ Similarly, a weak pulse as a sign of apoplexy is indeterminate: commenting on Thomas Sydenham in the early eighteenth century, William Salmon claims that, in apoplexies, the pulse is sometimes 'great, unequal and intermitting, sometimes languid and sometimes swift'. ${ }^{4}$ As another physician submits, if the pulse is strong during apoplexy, there is hope of recovery, for 'tis an argument that the Brain is not wholly overflowed'. ${ }^{45}$ The famous Leiden physician Herman Boerhaave insists that the pulse is 'most times' strong in apoplexy, 'when of a sudden, the Action of the five external and all the internal Senses is abolished together with all the voluntary Actions, and there remains only the Pulse ... and Breathing ... together with an appearance of a deep and everlasting Sleep'. ${ }^{46}$ The physician Giorgi Baglivi is unequivocal: 'the larger the Pulse grows, the sooner the Patient dies' ${ }^{47}$ In apoplexy, as in many other conditions, the pulse follows the motility and strength of the animal spirits: as John Floyer notes in 1707, if the spirits are strong, the pulse is great, but when spirits are weak, the pulse is 'unequal, intermitting, slow, rare'. In a 'vehement Apoplexy, the Pulse is languid, small, and quick and hard'. ${ }^{48}$

Perhaps due to its uncertain ensemble of symptoms and signs, there is rich literature in which several early modern physicians and surgeons devoted significant effort to understanding apoplexies, lethargies and convulsions. In 1689, for example, William Cole offers an history of the distemper, its cures,

\footnotetext{
${ }^{40}$ John B. Hicks, An Inaugural Dissertation on Compression of the Brain from Concussion (New York: T. and J. Swords, 1793), $12,21-2,27-8,13$.

${ }^{41}$ John Quincy, Lexicon Physico-Medicum, 3rd edn (London: J. Osborn and T. Longman, 1726), s.v.

${ }^{42}$ Worger's condition resembles a number of different distempers, including several sleep disorders. For example, 'caro' (Kỏ $\left.\rho \circ \varsigma\right)$ is 'a deep, and profound sleep, with the hurt of the sense, and motion (the breathing only accepted) and likewise the imagination, arising from the impeded motion of the Animal Spirits' (Robert Bayfield, Tes iatrikes kartos, or a Treatise de morborum capitis essentiis and prognosticis [London: D. Maxwell, 1663], 74); sleep disorders are caused by too much phlegm, blood, or 'Immoderate Vapors' in the brain, by narcotics, and are treated with similar regiments, including bleeding an attenuated diet, errhines, and other stimulants

(John Pechey, The Store-House of Physical Practice [London: Henry Bonwicke, 1695], 13, 15).

${ }^{43}$ Peter Paxton, A Directory Physico-Medical, Compos'd for the Use and Benefit of All such as Design to Study and Practice the Art of Physick (London: J. Sprint, 1707), 194, 196-7.

${ }^{44}$ Thomas Syndenham, Praxis Medica. The Practice of Physick: Or, Dr. Sydenham's Processus integri, Translated out of Latin into English, with Large Annotations, Animadversions, and Practical Observations on the Same ... [by William Salmon], 2nd edn (London, 1707), 164.

${ }^{45}$ William Cole, A Physico-Medical Essay Concerning the Late Frequency of Apoplexies (Oxford: Theatre, 1689), 128.

${ }^{46}$ Boerhaave's Aphorisms: Concerning the Knowledge and Cure of Diseases, in J. Delacoste (trans. and comm.) (London, 1725), 264; Sydenham [Salmon], op. cit. (note 44), 159.

${ }^{47}$ 'I observed at Rome, 1695,' Baglivi writes, op. cit. (note 22), 'in the Case of an Old Woman, who after she had been apoplectic for four Days, had a large and brandishing Pulse about ten a Clock at Night, and died about four the next Morning' (92).

${ }^{48}$ John Floyer, The Physician's Pulse-Watch, 2 vols (London, 1707), 1.111. This notion is Galenic.
} 
including tobacco, and argues against the use of cephalics and snuff. What he notices is an uptake in apoplexies and convulsions, largely due to cold and to changing qualities of air: in 1670, 1695 people died from convulsions, according to the bills of mortality, but in 1687, nearly 4000 died, while apoplexies proper increased, unevenly, in the same years, from 79 to 110 . Cole treats them as the same illness. ${ }^{49}$ The condition is understood largely as a superabundance of phlegm up until the seventeenth century, when autopsies disclose sufferers' brains as plethoric; later in the eighteenth century, it was understood as a 'vascular disease'. For Catherine Storey, eighteenth-century conceptions of the condition were founded not on previous nosologies but guided by clinical experience. ${ }^{50}$ Theophile Bonet's extensive case histories of apoplectics demonstrate as much, as does William Cullen's detailed classification. ${ }^{51}$ Thomas Willis' Two Discourses Concerning the Souls of Brutes (1683, Latin 1672) argues that apoplexy is a disease caused by an eclipse', suppression, or extinguishing of the animal spirits, in the callosum, which in turn affects all rational and most vital functions. As other physicians have argued, Willis continues, either there is far too much blood in the brain or an abundance of humours stop up the spirits themselves, the nerves either obstructed or inundated. The aetiology varies, for he once opened the body of an apoplectic and determined that an 'afflux' of blood was the cause. Thus, Willis offers either the 'profligation or extinction' of the spirits, meningeal ulcers, cranial extravasation and, the contraction of medullary pores as causes. ${ }^{52}$ For Boerhaave, apoplexy's causes are multiple but include disposition (large head, short neck, 'big and fat Body'); plethora; wounds, bruises, fractures; peccant humour; gluttony, hard drinking, 'too much thinking' - all of which alter the flow of animal spirits. Chief amongst causes are 'prejudicial violent Passions of the Mind, and the too great application of any sort of Business that requires too much Thought'. ${ }^{33}$ The condition's magnitude is measured by the age and constitution of the patient, but true apoplexies affect the sensorium commune, the common sense, a faculty assumed to draw coherently together data from external senses. Suffers of 'fierce true Apoplexy' seldom live more than 7 days. ${ }^{54}$

Boerhaave calls its proximate cause 'a sluggish Glew', which Salmon, commenting on Sydenham, explains as 'a Grumous thick Matter, not much unlike thick Milk for Substance', a mixture of blood and lymph. Either blood or lymph or this 'glew', through a blow or a fall, strikes and compresses the meninges of the brain, inducing paroxysm. This morbific matter alters or interrupts the flow of animal spirits. ${ }^{55}$ John Catherwood's 1715 definition is fulsome and one that epitomises contemporary descriptions. 'Tis then an Apoplexy when the Body is suddenly depriv'd of the chief Animal Faculties', he writes:

as well internal as external, and all voluntary Motion, so that the Animal Spirits are either deny'd a Passage from the Brain, or an Entrance into it; the Ventricles or Pores of the Brain being either compres'd from a Contusion, or obstructed from a Plethora, Poisons, Medicines endued with a Narcotic Faculty, which so alter the Blood, Lymph, and other Fluids, as to render 'em unfit to pass freely thro the Arteries of the Brain, whereby, thro the violent Impetus of the Heart, the Blood is so

\footnotetext{
${ }^{49}$ Cole, op. cit. (note 45), 6-19, 130-64, 190-6, 108-10.

${ }^{50}$ Catherine E. Storey, 'Apoplexy: Changing Concepts in the Eighteenth Century,' in Harry Whitaker et al. (eds), Brain, Mind, and Medicine: Essays in Eighteenth-Century Neuroscience (New York: Springer, 2007), 236, 234.

${ }^{51}$ H. S. Schutta and H. M. Howe, 'Seventeenth-Century Concepts of “Apoplexy” as Reflected in Bonet's Sepulchretum,' Journal of the History of the Neurosciences 15 (2006), 253-4, 260-1. Schutta and Howe offer a brief history of the condition. For Cullen, see Storey, op. cit. (note 50), 240-1; see also Francis Schiller, 'Concepts of Stroke before and after Virchow,' Medical History 14 (1970), 115-31.

${ }^{52}$ In Dr. Willis's Practice of Physick, in S. Pordage (trans.) (London, 1684), 153-6.

${ }^{53}$ Boerhaave, op. cit. (note 46), 264-8; see also Archibald Pitcairn, The Philosophical and Mathematical Elements of Physic, no trans. (London, 1718), 143; Sydenham [Salmon], op. cit. (note 45), 164-5, who includes his own tirade against snuff-taking.

${ }^{54}$ Boerhaave, op. cit. (note 46), 270.

${ }^{55}$ Ibid., 266; Sydenham [Salmon], op. cit. (note 44), 159, 160, 164-5. Amongst its causes are fractures, tumours, pathological bone growth, polyps, stagnation, as well as somatic disposition; see Joseph Browne, Institutions in Physick (London: W. R. for Jonah Browne, 1714), 249-50; Peter Shaw, A New Practice of Physick, 2 vols (London, 1753), 1.1-2. Lifting silently from Pitcairn, op. cit. (note 53), 144, in Quincy's Lexicon an apoplexy is 'produced by any Cause which hinders such Undulation of all the Nerves', a process whereby nervous fluid is constricted and driven back 'towards the Brain' (s.v.). See Schutta and Howe, op. cit. (note 51), 260, for similar views.
} 
wedg'd in, that it causes a Stagnation; and oftentimes Polypuses are form'd in the Carotids, Sinus's, and Vertebral Arteries, so that all the Spirits indulgent Nature can rally to support the Fabric, are detach'd to the Muscles of the Thorax, to perform Respiration, without which the Patient is inevitably lost. 56

Three factors dominate: obstruction of the spirits, thickening or stagnation of the blood and lymph and the formation of polyps. As Packe claims, in apoplexies like Worger's, the cause of distemper and death is 'Stagnation of the Blood in the Vessels' not 'Extravasation upon the Membranes, Brain, or Cerebellum' $(\mathrm{P}, 54-5)$. This jibes with his diagnosis, for extravasation is often the result of injury from a blow to the head or a fall. Whatever the cause, the problem is free passage: the spirits are hindered, blood pools and stagnates and the body evacuates the brain of spirits in order to sustain the heart and lungs. ${ }^{57}$ In its severity, this distemper is frequently mortal.

'No general Rule can be laid down for the Cure of it ...' So writes Boerhaave in his account of apoplexy: cures vary as causes vary. Physicians commonly used 'attenuating medicines' to evacuate morbid, sluggish matter, lessening the pressure on the brain. ${ }^{58}$ With Salmon's caveat in mind - 'no Physician ought to ... promise to cure a Total or Strong Apoplexy'59 - treatments conform to a standard roster: bleeding, blisters, clysters, setons, purgatives and cephalics, a 'thin' diet. The patient should be laid on his back, head raised or seated upright. ${ }^{60}$ Boerhaave's instructions are typical: let blood, purge repeatedly, administer diuretics and emetics and avoid 'medicines which strongly stimulate, stir up and heat' ${ }^{61}$ As with many distempers, remedies address most non-natural categories: the patient should fine 'clean' air and exercise 'as much as they can'. Salmon alights on the passions: 'Let nothing be represented to, or come near the Patient, which may cause Anger, Grief, or Sorrow, or put him into any Fears or Frights, nor indeed into any excessive Joy; for the result of all Passions, of what kind soever, are in this Disease always detrimental to the Sick'. ${ }^{62}$ Upright, in good air, exercised, bled and shielded from vehement feeling, a patient with mild apoplexy could hope for recovery.

About phlebotomy itself, opinions vary quite widely. Packe had bled Worger of ' 44 ounces in 26 hours time'. His contemporary, William Cole, recommends bleeding ' $30,40,50$, or 60 , or perhaps more, ounces at a time', while William Black cites Galen's view that no more than 18 ounces should be bled at one time. ${ }^{63}$ Boerhaave recommends bleeding with caution, since a patient's strength is quickly exhausted by evacuation: physicians must judge carefully each individual case, with this maxim in mind: ... bleeding doth kill, if it doth not instantly relieve. ${ }^{64}$ Some forbid bleeding altogether, as it 'diminishes' the blood and 'animal powers', weakening the sufferer. ${ }^{65}$ Catherwood advises against not only phlebotomy, as it was then practised, but against emetics, too, for following bleeding with purging is 'pernicious'. Arteriotomy is preferable, for 'bleeding out of the veins and other usual methods of practice; they prey upon and exhaust the animal spirits and confirm the distemper, rather than relieve the patient'. ${ }^{66}$ Patients were not

\footnotetext{
${ }^{56}$ John Catherwood, A New Method of Curing the Apoplexy (London: J. Darby for W. Taylor, J. Browne and Edward Symon, 1715), 2-3. As Salmon notes in his commentary on Sydenham, an apoplexy involves 'the depression of the Powers of the Animal Spirits', itself indicative of cure (Sydenham [Salmon], op. cit. [note 44], 162-3).

${ }^{57}$ There are more complex notions of the disease, too: Baglivi, op. cit. (note 22), see apoplexies as either sanguine or phlegmatic, their severity judged by 'the greater or lesser Difficulty of Respiration' (90-1), while Pitcairn, op. cit. (note 53), divides the condition into sorts which pressure either the brain with extravasation or dilate the arteries with plethora (144-5, 142, 151); Schutta and Howe, op. cit. (note 51), 254-7 for Bonet's and others' views.

${ }^{58}$ Boerhaave, op. cit. (note 46), 271, 274.

${ }^{59}$ Sydenham [Salmon], op. cit. (note 44), 167.

${ }^{60}$ Shaw, op. cit. (note 55), 1.3-7.

${ }^{61}$ Boerhaave, op. cit. (note 46), 273; Pitcairn, op. cit. (note 53), 146-8. This is not dissimilar to ancient treatment; see Black, op. cit. (note 36), 59, 70 .

${ }^{62}$ Sydenham [Salmon], op. cit. (note 44), 167-8.

${ }^{63}$ Cole, op. cit. (note 45), 173, 184-90; Black op. cit. (note 36), 97.

${ }^{64}$ Boerhaave, op. cit. (note 46), 272.

${ }^{65}$ Sydenham [Salmon], op. cit. (note 44), 160-1.

${ }^{66}$ Catherwood, op. cit. (note 56), 19-20, 28-31, 2, 5-9.
} 
always 'relieved': Pitcairn recommends rousing the apoplectic with 'things which excite pain', like cupping glasses, as well as noisome scents, errhines. Should these techniques fail, 'a burning hot Iron may be put to the Head or Neck, or both; for this makes both Pain and an Evacuation'. ${ }^{67}$ Another physician urges 'Burning the Extremities of the Fingers and Toes' in order to stimulate the animal spirits and fermentation in the blood. ${ }^{68}$

Medical efforts to stimulate an apoplectic patient thus contradict a prescription of opium, the effects of which were well-known: it eases pain, prevents evacuation, diverts the mind from disagreeable notions and relaxes nervous fibres so that the force of a painful stimulus is eluded or destroyed. Indeed, by diluting digestive juices, an 'agreable Plenitude' is induced, in turn entertaining the mind with 'ideas of satisfaction and delight'. Taking opium brings on sleep, affects both body and mind and induces the kind of pleasure that arises from satiety. Thinking ceases. But it also might inflame the stomach and rarely the blood - and even inspire apoplexy itself. ${ }^{69}$ Gray concludes that 'all judicious physicians and surgeons' would never prescribe opium for apoplexies, lethargies or concussions $(\mathrm{G} 2,12)$. Gray, it seems, was correct, as I have not found one physician who endorses the use of opium for paroxysms or apoplexies. If, in fact, Worger's death resulted from apoplexy, then his rival's treatment, 'two Grains and a quarter of Opium' is 'absurd' (G1, 8; G2, 3). The opium merely intensified Worger's 'stupor' $(\mathrm{G} 2,12)$.

Citing contemporary luminaries, ${ }^{70}$ Packe strongly disagrees, and advances opium's rarefying capacities, noting that the narcotic was given as part of a regimen, in 'moderate' quantity, combined with other drugs $(\mathrm{P}, 23,66,70)$. Defending his prescription, Packe acquaints us with his case-taking, first describing Worger's appearance, and then speculating about its causes: initially, he 'reckons' Worger was afflicted with a lethargy, or an apoplexy by concussion, and then claims that lethargies and concussions are species of apoplexies. Even palsy is 'a ruling symptom' of apoplexy. His point is that all of Worger's practitioners mistake treating the fall for treating his current condition, 'Great Distention of the Vessels all over the Pia mater and the Brain itself, and thus he stands by his prescription: his bolus was meant only to attenuate congealed blood and lymph, to restore circulation in the brain. Administered in Packe's manner, opium is salutary. In fact, his concoction revived Worger's sense, speech, and motion so that he was afterwards well enough for four bleedings (P, 64-65): Gray is as ignorant of opium's salutary effects as he is of its proper dose. Further, the autopsy proves - by revealing only tiny fissures in the skull - that the fall was not so violent (P, 61-62, 63). Prefacing his section on drugs, Packe avers that Gray ignores 'Physical Truth': this 'heap of Reflections', which Packe lists as a pageant of 24 offences, evidences Gray's 'Sullen Envy' and rage (P, 58-59).

These competing, often contradictory accounts are sustained by the ambiguity of Worger's symptoms and signs, by the fundamental uncertainty of eighteenth-century medical semeiotics. In turn, uncertainties about the causes of the patient's condition warrant divergent regimens of care and shift some attention away from the distemper to the skills and authority of the physicians: Packe musters constituents of the latest medical thought, while Gray adheres to conventional, mostly ancient views about fractures and their treatment. Both practitioners vie for mastery over Worger's case, and thus there are moments when invective overwhelms the 'honour' with physicians are meant to treat and address one another, where personal trumps professional feeling. My last section treats the tone and substance of the debate as they impinge on the physicians' status, reputation and clinical practice.

\footnotetext{
${ }^{67}$ Pitcairn, op. cit. (note 53), 148-149; Sydenham [Salmon], op. cit. (note 44), also recommends errhines as most effective, and he prescribes both Galenic and chymical medicines (162, 173-4).

${ }^{68}$ John Purcell, A Treatise of Vapours (London: Edward Place, 1707), 180.

${ }^{69}$ Richard Mead, A Mechanical Account of Poisons (London, 1708), 148, 147, 152; Catherwood, op. cit. (note 56), offers his opinion about prescribing opium: laudanum may cause apoplexy, by altering the texture of the blood, making more fluid the humours, and 'hurrying' the spirits into 'disorderly Motions,' causing delirium, even madness (39-41).

${ }^{70}$ John Freind, The History of Physick; from the Time of Galen to the Beginning of the Sixteenth Century, part two (London: J. Walthoe, 1725), 203, on opium.
} 


\section{Character and conduct}

At one point in their struggle, apparently Gray threatened to send the case to the College of Physicians for adjudication. Packe's response is telling:

the College of Physicians ... are the Judges of the World to whom I would appeal, tho' I should think myself very Impertinent, if I should trouble any of them Unask'd, with my Disputes. Their Learning and Candour is with Reverence and Pleasure remember'd by $M e$, who have been thrice examine'd by the Worthy President and Censors of that Honourable Society for their Fellowship, not at all to my Discredit (if I am not flatter'd by my Friends) and by them admitted into it in all the Customary Forms. To several of these worthy Gentlemen, have I been known many Years in the Practice of Physick, very much to my Improvement, and by some of the most eminent of them Worthily recommended to this Place, where nobody but Dr. Gray pick'd me out for a Blockhead.

Sure of his vindication, Packe confidently invites the scrutiny of his fellows, noting his dedication to learning, to his profession and his history with the College. Packe then demands that Gray provide him with 'his Bills for Mr. Worger, with an account of his whole method of Practice', with affidavits from himself and the surgeons, concluding with an impatient, hortatory appeal: a 'Man of Skill and Honour' should learn from his betters, and acknowledge his mistakes, as should any 'Gentleman, Scholar, and Physician' $(\mathrm{P}, 25)$. Such an appeal may have had little effect, as it was issued during the period in which there were significant shifts in the power and status of the College. As Harold Cook has shown, the College was more or less emptied of its regulatory and disciplinary power by the early eighteenth century, becoming 'a professional organisation'. It was riven by factions, unsure of its legal powers, and increasingly divided about its own future. If the failure of the 'old medical order' was in fact an inability of learned physicians to maintain their roles as judges of other practitioners, and of one another, the Packe-Gray dispute discloses this failure, in nuce. ${ }^{71}$ Still, Packe has membership, or near membership, in a club defined by learning and candour.

Similar sentiments animate his conception of his vocation. At the end of Ankographia, Packe retails his erudition and experience in comments on ideal practitioners of physic - appropriately enough in a chorographical text for, since antiquity, local knowledge of 'the country, the Seasons, the People, and particularly their Endemical Diseases' is the foundation of 'judicious and successful Practice'. Physiology is anchored in landscape, and knowledge of the climate, the air, terrene effluvia, he claims, distinguishes true from 'Vulgar Artificers', who, with a few common remedies and 'Politick Fetches', or tricks, malign the profession. His analogy is drama: these charlatans are merely actors whose names are lost to posterity (106-7). These are abiding views, at least from the perspective of learned physicians. In 1726, for example, John Freind advises patients on choosing practitioners, arguing that the learned, with their 'genius and sagacity', are to be preferred before empirics. He is 'well vers'd in ... the writings of the ancient Physicians' will, with experience, exceed all others. ${ }^{72}$ Packe fits this learned bill, and he is no stranger to defending, with prolixity, his thought or his practice, his constancy or conduct, in manuscript or in print. ${ }^{73}$ He notes that Gray 'should Blush' at his own transgression against 'liberal Education', that, even against Packe's own disposition, his libels demand response. 'What Regard to Rules of Justice or Good

\footnotetext{
${ }^{71}$ Cook, op. cit. (note 16), 210-11, 224-7, 255ff; see Lyn Bennett, Rhetoric, Medicine, and the Woman Writer 1600-1700 (Cambridge: Cambridge University Press, 2018), ix-xii, 1-6, passim.

${ }^{72}$ Freind, op. cit. (note 70), 60-4.

${ }^{73}$ See, eg., the defence of Packe's consultative activities in Charles Gibbs, A Letter to a Gentleman in London, Occasion'd Chiefly by Doctor Guybon's Letter to a Friend, to which is Annexed, the Particular Case Pointed at in the Letter as it was Justly Stated by Doctor Pake of BURY ... (Norwich, 1723). Several figures, including physicians and surgeons, testify that Packe was not the physician in the case of a young man, 16, who died from a tumour, or exotosis, but a consultant only, and thus not culpable for the boy's death (12-16). See Francis Guybon, A Letter to a Friend, in Answer to Mr. Gibb's Letter ... (Norwich: W. Chase, 1724), esp. 15-18, for Packe's involvement.
} 
Manners did he pay, when he forc'd his Surgeon upon my Patient ...?' In this, and some of his other manoeuvres, Gray uses 'low Arts', mean diction, improper quotation, and a 'Vermicular Style' (P, 57, 21).

To these 'low arts', Packe retorts with A Reply to Dr. Gray's Three Answers to a Written Paper, Entitled $M r$. Worger's Case is replete with footnotes citing manuscripts, case histories, affidavits, ancient and contemporary medical authorities. His prose is filigree, his periods Ciceronian and he lards his text with quotations from literary sources familiar to the learned. His is a 'vindication' for, as he notes in the preface, his knowledge, his method, he was 'sensible' that his 'Character was everywhere treated'. Instead of the conventional, polite genres and modes not 'foreign' to the profession, axioms and aphorisms, cases and consilia, and in place of an exchange in Latin, in order to present their disagreement 'to the Learned' $(\mathrm{P}, 69)$, his opponent proffers 'Affirmations, Certificates, and Oaths'. 'AFFIDAVITS are very Unusual arguments among Physicians', he writes in the preface. He must, he concedes, fight fire with accelerants, including repeated appeals to professional, gentlemanly status, to 'Men of Sense', to the obligations and constituents of free and fair public discussion embraced by licentiates, candidates and fellows of the college. The pamphlet is organised into a preface; a day-by-day account of Worger's illness, with treatments and prescriptions, that is presumably the 'paper' Packe circulated about the case $(\mathrm{P}, 1-6)$; a deposition by 'St[ephen?] Durant' about the state of Worger's head that found the pia mater turgid, but no 'extravasation of Blood' (P, 7); letters from Packe and Gray, transcribed, Packe claims, from originals or recovered by memory (P, 8-13); Packe's conclusions about the case (P, 13-16); letters about their pamphlet controversy in October and November 1726 (P, 17-26); eight 'affirmations and affidavits' from Packe and others (P, 27-35); Packe's animadversions and disagreements with Gray; consultations and disputes about trepanning and bleeding; Gray's refusal to publish his case history; their disagreements about specific prescriptions and therapies, especially Packe's use of opium (P, 36-70); and, finally, a page of references and errata $(\mathrm{P}, 71)$. As a rhetorical performance, the pamphlet is at times wan, at times rebarbative, but mostly focussed on Packe's person and status. His title page quotes Juno's pronouncement, from Horace's Odes, that victory over tyranny is secured by men 'of firm, righteous will', signalling not only his erudition, but advancing his moral status: against Gray's vacillation, Packe is constant.

While Gray promises to do 'what becomes a Gentleman' should Packe malign his testimony (G2, 13), Packe repeatedly retails his erudition. The section of his pamphlet concerned with rebuking Gray is prefaced with three quotations, meant to establish his dignity, shrewdness, acuity and magnanimity. ${ }^{74} \mathrm{~A}$ Latin quotation from Pufendorf s De jure naturae (1672) prefaces the affidavits to the effect that there is little point in swearing an oath if one is to refute it, or there is a danger of impugning the very nature of 'mutual signs' (intervenientibus signis), language itself. Oaths, then, must be true and binding $(\mathrm{P}, 27){ }^{75}$ He then disjointedly quotes Montaigne's 'De l'art de conferer', in order to signify truth as his animating concern (he offers a mawkish paean to truth at $\mathrm{P}, 66-67$ ): 'When someone opposes me, he arouses my attention, not my anger. I go to meet a man who contradicts me, who instructs me. The cause of truth should be the common cause for both. ... When you win the advantage for your proposition, it is truth that wins; when you win the advantage for order and method, it is you who win' $(\mathrm{P}, 36)$. From the first passage, Packe omits the following: 'What will he answer? The passion of wrath has already smitten his judgement. Confusion has seized it before reason'. This essay is a complex meditation on the ways in which style and politics - 'number and weight' in Montaigne's terms - are entangled, of the ways in which we mistakenly attribute wisdom to those in power, when their rise is often the result of commonplace thinking or chance. Montaigne celebrates his capacity to amend: some do not have the 'courage to correct because they have not the courage to suffer being corrected'. Against Packe's willingness to learn, to adjust his views, to engage in convivial debate, the implication is that Gray is

\footnotetext{
${ }^{74}$ Packe's self-presentation is conventional; similar claims are explored in several recent studies of the 'roles' and personae of natural philosophers in early modern Europe; see, for example, The Philosopher in Early Modern Europe: The Nature of a Contested Identity, Conal Condren et al. (eds) (Cambridge: Cambridge University Press, 2006).

${ }^{75}$ Samuel Pufendorf, De jure naturae et gentium (Frankfurt, 1794), 4.2.476-7; The Law of Nature and Nations, Basil Kennet (trans.), 5th edn (London, 1749), 340.
} 
occasionally, unintentionally correct, but that his assertions are unwarranted, without rationale, vituperative: 'Obstinacy and heat of opinion is the surest proof of stupidity'. ${ }^{76}$

The third quotation is from 'Of Trifling Propositions,' in Locke's Essay Concerning Human Understanding, in which Locke laments the 'trifling' nature of discourse and debate when parties are at liberty to determine arbitrarily the significance and meaning of names for various substances. These are tricks of fancy $(\mathrm{P}, 36)$. His example is the soul: we can speak endlessly of substance, man, animal, form, vegetative, sensitive and rational qualities 'without knowing what the Soul really is'. ${ }^{77}$ Packe's point, I think, is to attack Gray's terms, to make trifling his substantive claims. Taken together, the force of these epigraphs advances Packe's equanimity, his scholarly bona fides and his attention to semantics, testimony and truth. In precisely this vein, his 15 October 1726 letter to the Canterbury News-Letter accuses Gray of failing 'to observe the Niceties requisite of a Gentleman and Physician', of scholarly misconduct by 'abusing some Fragments of my Letters and his own' in the Further Answer, and by 'poorly epitomizing my Manuscript'. Gray is 'truly Ridiculous to all Persons of Sense' (n. p.).

Gray charges Packe with mendacity, overmuch passion, greed and pugnacity. He lies about his dismissal by Mrs. Worger, who urged her healthy brother to fire Packe, after settling his fees. Apparently, Packe refused payment, even after Gray had been conscripted, 'desiring to be employ'd again' the very next day, Thursday, 14 April. The surgeons agree (G1, 7). At their incendiary first meeting, Gray reports that he 'declar'd, That the Patient was in utmost Danger; but Dr. Packe said, He did not doubt of his Recovery if he was left to his Care [Packe's care] alone' $(\mathrm{G} 1,8)$. Later, meeting in Worger's sickroom, Packe appears 'with an air of Displeasure' and inquires how Worger's family should hire Gray 'without advising him first'. Gray replies that he had sent along a surgeon to inform the physician. But Packe fell into 'an unwarranted Passion' and that, to Gray, was the 'occasion of his Dismission' (G2, 6). Gray mollifies: he desire to 'avoid Dispute' with Packe, considering only the life of the patient.

In these and other interactions, to Gray Packe is taciturn or angry, sometimes exhibiting 'violent Passion', and he is 'imperious' with Crayford and Botting, dismissing or silencing the surgeons (G2, 4-5). Indeed, on Thursday 14 April, having met on the road to Hinxhill, there was a 'Fray (by way of Skirmish) between Packe and one of the surgeons, but there was no bloodshed' (G2, 9). While Packe and Crayford are debating bleeding the patient, Gray demurs: he refuses to engage 'hot Words' (G2, 5). After Packe is dismissed, Gray assumes he can care for Worger unmolested. Not so. On the same day, Thursday 14 April, Packe sends Gray no fewer than seven letters, demanding presence at the bedside. Gray renders Packe's second letter as follows:

That he believes that we two should have compromis'd the Matter about Bleeding, if Bully Crayford had not put in with his barbarous pick-pocket Proposal of Trepanning a Man, who had not so much as a broken Head; that he detests the Man, and wou'd have nothing to do with him; that in this Case his Honour is concern'd, and he will see it through, and perhaps make a farther Enquiry into his Trepans: However, he says, he would meet us both at Philippi, if he could learn our time. $(\mathrm{G} 2,6)$

Gray's reply is sarcastic - Packe's allusion is 'foreign to the Purpose' but the chemist frequently trades in apparitions $(G 2,7)$, while Packe argues that his letter, in which he requests bills from Gray and his apothecary, is 'as Intelligible ... as the Ghost would have spoke it, if he had met him at Phillipi' (P, 21). Likely gleaned from Plutarch, this rather grandiose invocation of Caesar's ghost appearing to Brutus on the eve of battle at Philippi is in keeping with Packe's claims to erudition. Widely available in Shakespeare's rendition, in which Caesar's ghost, perhaps Brutus' own 'evil genius' or daimon, foretells Brutus', his murderer's, death, the moment conjures an admixture of Brutus', and Gray's, lack of selfknowledge, revenge for past misdeeds, and ineluctable failure. Packe assumes the apparition's role, foretelling the unevenly learned doctor's defeat, his own revenge. Perhaps, too, it pleases Packe that the

\footnotetext{
${ }^{76}$ Montaigne, op. cit. (note 25), 704-17.

${ }^{77}$ John Locke, in Peter H. Nidditch (ed.), Essay Concerning Human Understanding (Oxford: Oxford University Press, 1975), 4.8.9-10, 615-6.
} 
surgeons would be, by most accounts, comparatively poorly educated and thus confounded by the allusion. ${ }^{78}$

Gray's reading of Packe's furious letter writing is clear: the physician is concerned with honour, with reputation, with fees, with hierarchies of practice. Packe had been summarily fired, but persisted in using 'the most artful Endeavours to be employ'd again' (G2, 7-8) even telling Worger's nurse that he would waive future payment $(G 2,8)$. Furthermore, Gray asserts that Packe - arrogant, recalcitrant, banking on 'success' - offers to wager 'fifty Guineas' that he could 'perform a Cure beyond the Reach of the rest of Mankind' (G2,11). As Gray laments, 'I do not expect ever to see the Doctor part with any Notion when he has once got it' $(G 2,13)$. These 'notions' clearly includes his reputation, his honour, his professional status.

Packe concludes his riposte in high dudgeon, demanding that Gray justify injury to Packe's character (P, 70). Similarly, his letter to the Canterbury News-Letter requests Gray's charges and prescriptions, and appeals to 'a common Share of Learning ... and strict Integrity' that distinguishes their profession (n.p.). Of course, the point of their controversy is that neither one wishes blame for Worger's death, a member of a powerful enough family to not only secure an ensemble of practitioners for his accident and illness but to inspire months of public debate, discussion, 'calumnies'. They both employ classical and modern medical thought and established legal means - Packe cites more than 50 ancient and modern sources, and both gather witnesses of varying expertise - as well as conventional ethical appeals. Around this star forms a constellation: discourse and conduct, clinical mien and collegial misbehaviour, manifest in these physicians' importuning and arrogating, belittling and jousting. By their own standards, both physicians act poorly: as Worger's crowded sick-room and the Kentish village itself become scenes of roiling discord, in which two physicians find themselves at odds, often 'warmly', over what Gray calls Packe's overweening 'Delicacy of Taste. ${ }^{79}$ That 'professional feeling', in Hamilton's terms, is forged in struggle for mastery over the case, for reputation - is perfectly evident in the Packe-Gray affair. A quarrel about 'physical facts' devolves into professional and personal opprobrium, replete with questions of intellectual and ethical integrity, comportment and passion, played out in private and public chatter.

Acknowledgements. The author thanks anonymous reviewers, the editor of Medical History, Helen Orr Christou, Lyn Bennett, Trevor Ross and Isabelle Milot for reading and commenting on earlier drafts of his paper, the funding for which was provided by the Social Sciences and Humanities Research Council of Canada and by the Faculty of Arts and Humanities and Social Sciences at the University of Windsor for funding this research.

\footnotetext{
${ }^{78}$ The passages in question, followed by a debate about the status of visions, dreams, and the imagination, are Plutarch, 'Brutus' and 'Caesar,' Plutarch's Lives, Bernadotte Perrin et al. (trans.) 11 vols (London: Heinemann, 1918), Vol. 6, \$\$36-37 and Vol. 7, \$39. For Shakespeare’s Julius Caesar, 4.3.273ff. see, eg., Stephen M. Buhler, 'No Spectre, No Sceptre: The Agon of Materialist Thought in Shakespeare's Julius Caesar,' English Literary Renaissance 26 (1996), 313-32.

${ }^{79}$ Copies of Affidavits, $5,6$.
} 